\title{
EVALUATION OF THE CURVATURE OF THE LONGITUDINAL FOOT ARCH IN CHILDREN AGED 7 AND 8 - A PILOT STUDY
}

\author{
Monika Niewiadomska, ${ }^{A, B, C, D}$ Maria Makris, ${ }^{A, D}$ Katarzyna Kotarska ${ }^{\mathrm{D}, \mathrm{E}}$ \\ University of Szczecin, Faculty of Physical Culture and Health Promotion, Poland

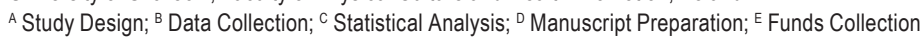 \\ Address for corpespondence: \\ Monika Niewiadomska \\ Faculty of Physical Culture and Health Promotion, University of Szczecin \\ Al. Piastów 40 b, bl.6, 71-065 Szczecin, Poland \\ E-mail: monikaniewiadomska@wp.pl
}

\begin{abstract}
Ahstract The foot is an essential part of the human body, and a key factor enabling mobility. The proper functioning of the foot depends on its morphological structure and on the proper shape of its arches - transversal and longitudinal. Having in mind that flat feet develop as a succession of different stages, it is important to systematically monitor the development of feet at various phases of a child's growth. Therefore, this study aims to evaluate longitudinal foot arch curvature in children aged 7 and 8 . The study involved 122 children (77 girls and 45 boys) aged 7 and 8 - students of a primary school in Bezrzecze near the city of Szczecin. Body height and weight, and the length and width of the feet were measured. A podoscope was used to determine the curvature of the longitudinal foot arch, which was then expressed on a scale compatible with the Szriter-Gudanow "KY" foot arch curvature index. This non-invasive method enables preventive measures to be taken at critical stages of a child's life. The results for the tested groups of children revealed statistically significant relationships for body height and weight, and the length of the feet between the 7 and 8 year olds. Furthermore, it was observed that the vast majority of the tested children has normal curvature of the longitudinal arch of both the right and left foot.
\end{abstract}

Key worlds longitudinal foot arch curvature, child, podoscope

\section{Introduction}

The foot is an essential part of the human body, and a key factor enabling mobility. We need feet to walk, run, and maintain a vertical posture. We also use them in a variety of essential daily activities.

The proper functioning of the foot depends on its morphological structure and on the proper shape of its arches - transversal and longitudinal. When walking, the foot arch with a proper curvature acts as a shock absorber which eliminates the negative impact of the applied loads and protects the internal organs and the central nervous system from micro-injuries. The proper structure and functioning of the foot may affect the development of other constituents of the motor system (knees, hips, spine). Improper curvature may lead to dysfunctions of ankle and 
foot joints, tendon strain, knee misplacement, which may ultimately and consequently lead to the deformation of the hip and spine.

Therefore, attention should be paid to the proper development of the feet of young children. Preschool and elementary school periods are stages of rapid growth of the body. A child between 3 and 7 gains weight slowly, but grows quite fast (5-7 cm a year). This rapid growth also includes the feet. When a child starts to walk and exercise various forms of physical activity, the shape of its feet is affected. At this stage, the bones are sensitive and susceptible, the muscles are weak, and the feet joints are characterised by high flexibility. At the age of 5 to 6 , the entire bone structure strengthens considerably, and the physiological curves of the spine take shape. The foot is characterised by a pronounced curvature of the longitudinal arch (Demczuk-Włodarczyk, 2003). Proper development of the foot is mostly affected by physical activity of the child, as well as its weight, and proper footwear (Kasperczyk, 1994). The outer structure of the foot consists of an arrangement of transversal and longitudinal arches, which extend under a load and, return to their initial state when the load is no longer applied. The development of flat feet can be divided into three main stages: muscular insufficiency, muscular insufficiency with severe changes, and the stage of structural changes in which the arches are permanently altered (Rykała, Snela, Drzał-Grabiec, Podgórski, Nowicka, Kosiba, 2013). The evaluation of the curvature of the longitudinal foot arch is a key element in preventive treatment of children at early school age.

The main purpose of this study was to evaluate longitudinal foot arch curvature in children aged 7 and 8 .

\section{Material and Methods}

In 2016 tests were carried out in the primary school in Bezrzecze near Szczecin in Poland. The tests involved the measurement of the curvature of longitudinal foot arch in children aged 7 and 8 . The study involved 122 children (77 girls and 45 boys) aged 7 and 8 .

Body height and weight, and the length and width of the feet were measured. A podoscope, i.e. a device for photographing the sole part of the foot, was used to measure the curvature of the longitudinal arch of the right and left foot. A podoscope can be used to examine the feet of children, adolescents, and adults. It provides a variety of essential information required to diagnose and treat a number of medical conditions. It can also be used to properly evaluate the shape of the foot, or the presence of skin swelling or corns. Operation of a podoscope is easy (www. podoskop.pl).

\section{Description of the test}

The patient wearing no shoes nor socks (i.e. barefoot) stands on the podoscope, and a full HD camera integrated with the device takes a picture. Then the podoscope sends the picture to a PC, which analyses the image to determine the relevant parameters of the feet.

The Szriter-Gudanow "KY" index, and the "Ky" index scale were used to evaluate the longitudinal curvature of the feet. As this scale does not include parameters for 7 year olds, the "Ky" index parameters for 8 year olds were used for children aged both 7 and 8 . 


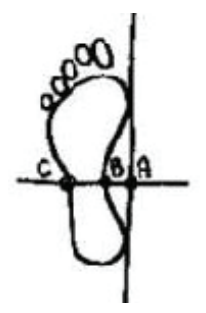

The level of statistical significance $p<0.05$ was used. The statistically significant results presented in the tables are marked with an asterisk $(*)$. Average, median and standard deviation values were also measured for the measurements of the curvature of the longitudinal arch under load and with no load. The Student test ( $t$ ) and Man-Whitney $(U)$ test were used to analyse the differences in the results for both groups (Petrie, Sabin, 2006).

\section{Test result's}

On the basis of the obtained test results we characterised the group in terms of the selected anthropometric features. The Shapiro-Wilk test was used to check the distribution of the variable with a normal distribution.

Table 1. Characteristics of the tested group of boys

\begin{tabular}{|c|c|c|c|c|c|c|}
\hline $\begin{array}{c}\text { Distribution } \\
\text { characteristics }\end{array}$ & $\begin{array}{c}\text { Body weight } \\
(\mathrm{kg})\end{array}$ & $\begin{array}{l}\text { Body height } \\
(\mathrm{cm})\end{array}$ & $\begin{array}{l}\text { L foot length } \\
(\mathrm{cm})\end{array}$ & $\begin{array}{l}\text { R foot length } \\
(\mathrm{cm})\end{array}$ & $\begin{array}{l}\text { L foot width } \\
\quad(\mathrm{cm})\end{array}$ & $\begin{array}{l}\text { R foot width } \\
(\mathrm{cm})\end{array}$ \\
\hline \multicolumn{7}{|c|}{ Boys aged $7 n=20$} \\
\hline Min-max & $18-33$ & $110-131$ & $16.8-26.7$ & $16.6-26.6$ & $6.6-10.3$ & $6.3-10.3$ \\
\hline$Q_{1}-Q_{3}$ & $21-25.5$ & $119-125.5$ & $22.2-24.5$ & $22.2-24.1$ & $8.3-9.6$ & $8.6-9.6$ \\
\hline Median & 23 & 121.3 & 22.75 & 22.9 & 9.15 & 9.1 \\
\hline$x$ & 23.5 & 121.2 & 23.1 & 22.9 & 8.9 & 9.00 \\
\hline SD & 3.8 & 5.3 & 20.8 & 20.6 & 8.9 & 9.6 \\
\hline Shapiro-Wilk test (p) & $(+) 0.32$ & (+) 0.76 & $(-) 0.02$ & $(-) 0.02$ & $(+) 0.35$ & $(+) 0.10$ \\
\hline \multicolumn{7}{|c|}{ Boys aged $8 n=25$} \\
\hline Min-max & $20-44$ & $120-143$ & $17.4-29.8$ & $172-303$ & $6.7-11.1$ & $6.6-11.7$ \\
\hline$Q_{1}-Q_{3}$ & $27-34$ & $129-135$ & $24.9-26.6$ & $24.8-26.8$ & $8.9-10.2$ & $9.0-10.2$ \\
\hline Median & 30 & 134 & 25.9 & 25.6 & 9.5 & 9.5 \\
\hline$x$ & 30.1 & 132.1 & 25.0 & 24.9 & 9.3 & 9.4 \\
\hline SD & 5.8 & 6.1 & 30.3 & 30.7 & 9.3 & 9.4 \\
\hline Shapiro-Wilk test (p) & $(+) 0.51$ & $(+) 0.57$ & $(-) 0.0007$ & $(-) 0.002$ & $(+) 0.14$ & (-) 0.03 \\
\hline
\end{tabular}

Table 1 characterises the parameters of the tested groups of boys. In the group of 7 year olds, the lowest measured height was $110 \mathrm{~cm}$, and the highest was $131 \mathrm{~cm}$. In the group of 8 year olds, the lowest height was $120 \mathrm{~cm}$, and the highest was $143 \mathrm{~cm}$. The difference in the averages was high and amounted to $10.9 \mathrm{~cm}$. The lowest body weight observed was respectively $18 \mathrm{~kg}$ and $20 \mathrm{~kg}$. The highest weight was observed in the group of 8 year olds (44 kg). The difference in average body weight amounted to $6.6 \mathrm{~kg}$ in favour of 8 year olds. The average width of the feet was also greater in case of 8 year olds $-0.04 \mathrm{~cm}$. 
The length of the feet for 7 year olds was in the range of $16.8-26.7 \mathrm{~cm}$ for the left foot, and $16.6-26.6 \mathrm{~cm}$ for the right foot. In the group of 8 year olds, the minimum and maximum values for foot length were $17.4-29.8 \mathrm{~cm}$ and $17.2-30.3 \mathrm{~cm}$ respectively. The difference between both tested groups was $1.91 \mathrm{~cm}$ for the left foot and $2.0 \mathrm{~cm}$ for the right foot.

Table 2. Longitudinal foot arch curvature characteristics for the tested group of boys

\begin{tabular}{|c|c|c|c|c|}
\hline Distribution characteristics & $\begin{array}{l}K y L_{0} \text { foot } \\
\text { (no load) }\end{array}$ & $\begin{array}{l}\text { Ky } R_{0} \text { foot } \\
\text { (no load) }\end{array}$ & $\begin{array}{c}\text { Ky L foot } \\
\text { (load) }\end{array}$ & $\begin{array}{c}\text { Ky R foot } \\
\text { (load) }\end{array}$ \\
\hline \multicolumn{5}{|c|}{ Boys aged $7 n=20$} \\
\hline Min-max & $0.23-0.57$ & $0.22-0.59$ & $0.29-0.61$ & $0.27-0.85$ \\
\hline$Q_{1}-Q_{3}$ & $0.27-0.42$ & $0.30-0.38$ & $0.40-0.49$ & $0.43-0.53$ \\
\hline Median & 0.33 & 0.32 & 0.46 & 0.46 \\
\hline$x$ & 0.34 & 0.35 & 0.44 & 0.48 \\
\hline SD & 0.10 & 0.09 & 0.08 & 0.12 \\
\hline Shapiro-Wilk test (p) & $(+) 0.13$ & $(-) 0.01$ & $(+) 0.98$ & $(-) 0.02$ \\
\hline \multicolumn{5}{|c|}{ Boys aged $8 n=25$} \\
\hline Min-max & $0.20-0.70$ & $0.23-0.60$ & $0.24-0.77$ & $0.30-0.80$ \\
\hline$Q_{1}-Q_{3}$ & $0.31-0.43$ & $0.30-0.42$ & $0.31-0.51$ & $0.36-0.45$ \\
\hline Median & 0.36 & 0.36 & 0.41 & 0.39 \\
\hline$x$ & 0.37 & 0.37 & 0.43 & 0.43 \\
\hline SD & 0.11 & 0.09 & 0.14 & 0.13 \\
\hline Shapiro-Wilk test (p) & $(+) 0.11$ & $(+) 0.37$ & $(+) 0.17$ & $(-) 0.0001$ \\
\hline
\end{tabular}

Table 2 shows the results for the curvature of the right and left foot arch under own-weight and with no load for the tested groups of 7 and 8 year old boys - based on the Szriter-Gudanow (Ky) index. The difference between the curvature under load and with no load points to a dynamic load-carrying purpose of the arch. The average longitudinal arch curvature of the right and left foot under own-weight load was 0.44 and 0.48 respectively for 7 -year old boys, and 0.43 for the left and right in case of 8 year olds. Based on the "Ky" index, these parameters correspond to the proper development of the longitudinal arch of the foot.

Tahle 3. Ky index value for tested groups of boys, with load applied

\begin{tabular}{|c|c|c|c|c|}
\hline \multirow{2}{*}{ Ky index } & \multicolumn{2}{|c|}{ Ky L } & \multicolumn{2}{|c|}{ Ky R } \\
\hline & $\mathrm{N}$ & $\%$ & $\mathrm{~N}$ & $\%$ \\
\hline \multicolumn{5}{|c|}{ Boys aged $7 n=20$} \\
\hline Above norm - lowered arch $>0.54$ & 4 & 20 & 4 & 20 \\
\hline Norm 0.44-0.54 & 13 & 65 & 13 & 65 \\
\hline Below norm - hollow arch $<0.44$ & 3 & 15 & 3 & 15 \\
\hline \multicolumn{5}{|c|}{ Boys aged $8 n=25$} \\
\hline Above norm - lowered arch $>0.54$ & 6 & 24 & 6 & 24 \\
\hline Norm $0.44-0.54$ & 14 & 56 & 14 & 56 \\
\hline Below norm - hollow arch $<0.44$ & 5 & 20 & 5 & 20 \\
\hline
\end{tabular}


As presented in Table 3, among both 7 year olds and 8 year olds the vast majority of boys has normal curvature of the longitudinal arch of the left and right foot. The proportion of children with lowered longitudinal arch in both groups is the same, and amounts to $20 \%$ for both feet.

Table 4. Characteristics of the tested group of girls

\begin{tabular}{|c|c|c|c|c|c|c|}
\hline Distribution characteristics & $\begin{array}{l}\text { Body weight } \\
(\mathrm{kg})\end{array}$ & $\begin{array}{l}\text { Body height } \\
(\mathrm{cm})\end{array}$ & $\begin{array}{l}\text { L foot length } \\
\quad(\mathrm{cm})\end{array}$ & $\begin{array}{l}\text { R foot length } \\
\quad(\mathrm{cm})\end{array}$ & $\begin{array}{l}\text { L foot width } \\
(\mathrm{cm})\end{array}$ & $\begin{array}{l}R \text { foot width } \\
\quad(\mathrm{cm})\end{array}$ \\
\hline \multicolumn{7}{|c|}{ Girls aged $7 n=33$} \\
\hline Min-max & $15-35$ & $108-134$ & $16.9-28.3$ & $16.2-28.4$ & $6.6-11.1$ & $6.9-12.1$ \\
\hline$Q_{1}-Q_{3}$ & $20-25$ & $115-125$ & $21.9-24.1$ & $22.0-23.8$ & $8.2-9.2$ & $8.3-9.0$ \\
\hline Median & 23 & 120 & 23.1 & 23.0 & 8.8 & 8.7 \\
\hline$x$ & 23 & 120.2 & 23.0 & 22.9 & 8.7 & 8.8 \\
\hline SD & 4.4 & 6.1 & 22.8 & 22.8 & 9.6 & 10.5 \\
\hline Shapiro-Wilk test (p) & $(+) 0.26$ & $(+) 0.82$ & $(-) 0.02$ & $(-) 0.009$ & $(+) 0.22$ & (-) 0.01 \\
\hline \multicolumn{7}{|c|}{ Girls aged $8 n=44$} \\
\hline Min-max & $20-37$ & $118-144$ & $19.5-33.0$ & $19.0-33.2$ & $7.0-12.1$ & $6.8-11.9$ \\
\hline$Q_{1}-Q_{3}$ & $23-29.5$ & 124-132 & $23.0-25.4$ & $22.8-25.5$ & $8.6-9.7$ & $8.5-9.5$ \\
\hline Median & 26 & 127 & 24.2 & 24.0 & 9.0 & 8.9 \\
\hline$x$ & 26.9 & 127.8 & 24.6 & 24.4 & 9.2 & 9.1 \\
\hline SD & 4.9 & 5.4 & 27.1 & 27.8 & 1.0 & 1.0 \\
\hline Shapiro-Wilk test (p) & $(-) 0.003$ & $(+) 0.22$ & $(-) 0.0008$ & $(-) 0.003$ & (+) 0.07 & (-) 0.04 \\
\hline
\end{tabular}

Table 4 characterises the parameters of the tested groups of girls. The average body height for 7 -year old girls amounted to $120.2 \mathrm{~cm}$, and was lower by $7.6 \mathrm{~cm}$ less than the average for the group of 8 year olds. The difference in body weight amounted to $3.9 \mathrm{~kg}$ in favour of 8 year olds. The same holds for the length of the feet. 8-year old girls had the left foot longer by $1.6 \mathrm{~cm}$ and the right foot longer by $1.5 \mathrm{~cm}$. For food width, the difference in the average values is also in favour of 8 -year old girls $(0.5 \mathrm{~cm}$ for the left foot and $0.3 \mathrm{~cm}$ for the right foot).

Table 5. Longitudinal foot arch curvature characteristics for the tested group of girls

\begin{tabular}{lcccc}
\hline Distribution characteristics & $\begin{array}{c}\text { Ky } L_{0} \text { foot } \\
\text { (no load) }\end{array}$ & $\begin{array}{c}\text { Ky } R_{0} \text { foot } \\
\text { (no load) }\end{array}$ & Ky L foot & Ky R foot \\
\hline Min-max & Girls aged $n=33$ & $0.27-0.68$ \\
$Q_{1}-Q_{3}$ & $0.20-0.73$ & $0.20-0.68$ & $0.36-0.52$ \\
Median & $0.29-0.40$ & $0.31-0.47$ & $0.26-0.77$ & 0.44 \\
X & 0.33 & 0.36 & $0.34-0.50$ & 0.45 \\
SD & 0.38 & 0.38 & 0.44 & 0.45 \\
Shapiro-Wilk test $(p)$ & 0.13 & 0.12 & 0.44 & $(+) 0.64$ \\
\hline & $(-) 0.13$ & $(+) 0.38$ & 0.11 & $(+) 0.19$ \\
\hline Min-max & & Girls aged $8 n=44$ & $0.26-0.82$ \\
$Q_{1}-Q_{3}$ & $0.20-0.61$ & $0.21-0.64$ & $0.22-0.80$ & $0.38-0.50$ \\
Median & $0.31-0.40$ & $0.32-0.44$ & $0.34-0.48$ & 0.45 \\
X & 0.33 & 0.37 & 0.42 & 0.45 \\
SD & 0.35 & 0.38 & 0.42 & 0.12 \\
Shapiro-Wilk test $(p)$ & 0.08 & 0.09 & 0.11 & $(-) 0.03$ \\
\hline
\end{tabular}


Table 5 Characterises the tested groups of girls in terms of the curvature of the longitudinal foot arch both under load and with no load. The arithmetic average for both feet for the tested groups is within the range of proper arch curvature for this age.

Table 6. Ky index value for tested groups of girls, with load applied

\begin{tabular}{|c|c|c|c|c|}
\hline \multirow{2}{*}{ Ky index } & \multicolumn{2}{|c|}{ Ky L } & \multicolumn{2}{|c|}{ Ky R } \\
\hline & $\mathrm{N}$ & $\%$ & $\mathrm{~N}$ & $\%$ \\
\hline \multicolumn{5}{|c|}{ Girls aged $7 n=33$} \\
\hline Above norm - lowered arch $>0.54$ & 6 & 18 & 6 & 18 \\
\hline Norm $0.44-0.54$ & 21 & 64 & 21 & 64 \\
\hline Below norm - hollow arch $<0.44$ & 6 & 18 & 6 & 18 \\
\hline \multicolumn{5}{|c|}{ Girls aged $8 n=44$} \\
\hline Above norm - lowered arch $>0.54$ & 4 & 9 & 4 & 9 \\
\hline Norm $0.44-0.54$ & 30 & 71 & 30 & 71 \\
\hline Below norm - hollow arch $<0.44$ & 10 & 20 & 10 & 20 \\
\hline
\end{tabular}

The curvature of the feet for girls is adequate. The vast majority of the tested girls (64\% of 7 -year olds, and $71 \%$ of 8 -year olds) has normal curvature (Table 6).

Table 7. Significance of the differences of the selected parameters between the tested groups of girls

\begin{tabular}{lcccc}
\hline \multicolumn{1}{c}{ Parameters } & $\begin{array}{c}\text { Samples } \\
(+;-)\end{array}$ & $\begin{array}{c}\text { Student's test } \\
(\mathrm{t})\end{array}$ & $\begin{array}{c}\text { Sample } \\
(+;-)\end{array}$ & $\begin{array}{c}\text { Man-Whitney test } \\
(\mathrm{U})\end{array}$ \\
\hline Body weight & +- & 0.0006 & + & $\mathbf{0 . 0 0 0 5 ^ { * }}$ \\
Body height & ++ & $0.0001^{*}$ & + & 0.0001 \\
L foot length & -- & 0.0080 & + & $0.0040^{*}$ \\
R foot length & -- & 0.0150 & + & $0.0100^{*}$ \\
L foot width & ++ & 0.0600 & + & 0.3300 \\
R foot width & -- & 0.2400 & + & 0.1400 \\
KyL $_{0}$ & -- & 0.3900 & + & 0.9200 \\
KyR $_{0}$ & ++ & 0.9800 & + & 0.9300 \\
KyL & +- & 0.5300 & + & 0.4700 \\
KyR & +- & 0.8200 & + & 0.8800 \\
\hline
\end{tabular}

* Significant with $p<0.05$.

A comparison between the tested groups of girls (Table 7) revealed statistically significant correlation between body weight and height, and the length of the feet, attributable to the physical development of the children of this age (Table 7). No statistically significant differences were observed in the longitudinal curvature of the feet in the girl group. It can be presumed that the arch at this stage does not yet undergo dynamic growth. This may raise concerns so as to the proper formation of the arch, as there exists a statistically significant correlation for the length of both the left and the right foot. This proves that the foot grows lengthwise, thus the bones expand. 
Tahle 8. Significance of the differences of the selected parameters between the tested groups of boys

\begin{tabular}{lcccc}
\hline \multicolumn{1}{c}{ Parameters } & $\begin{array}{c}\text { Samples } \\
(+;-)\end{array}$ & $\begin{array}{c}\text { Student's test } \\
(\mathrm{t})\end{array}$ & $\begin{array}{c}\text { Sample } \\
(+;-)\end{array}$ & $\begin{array}{c}\text { Man-Whitney test } \\
(\mathrm{U})\end{array}$ \\
\hline Body weight & ++ & $0.0001^{*}$ & + & 0.0002 \\
Body height & ++ & $0.0001^{*}$ & + & 0.0001 \\
L foot length & -- & 0.0150 & + & $0.0009^{*}$ \\
R foot length & -- & 0.0170 & + & $0.0009^{*}$ \\
L foot width & ++ & 0.1900 & + & 0.1400 \\
R foot width & +- & 0.2100 & + & 0.0900 \\
KyL & ++ & 0.3100 & + & 0.2700 \\
KyR & -+ & 0.4600 & - & 0.3000 \\
KyL & ++ & 0.6100 & + & 0.4400 \\
KyR & -- & 0.2700 & + & 0.0600 \\
\hline
\end{tabular}

${ }^{*}$ Significant with $p<0.05$.

The results obtained for the groups of tested boys were similar to those for the girl groups. Statistically significant differences were observed in the weight and height of the body, and in the length of the feet. At this stage, the longitudinal arch of the foot does not yet undergo rapid development, and the differences are not yet significant (Table 8).

Table 9. Significance of the differences of the selected parameters between the groups of 7-year old girls and boys

\begin{tabular}{lcccc}
\hline \multicolumn{1}{c}{ Parameters } & $\begin{array}{c}\text { Samples } \\
(+;-)\end{array}$ & Student's test & $\begin{array}{c}\text { Sample } \\
(+;-)\end{array}$ & Man-Whitney test \\
\hline Body weight & ++ & 0.71 & + & 0.67 \\
Body height & ++ & 0.54 & + & 0.48 \\
L foot length & -- & 0.95 & + & 0.58 \\
R foot length & -- & 0.95 & + & 0.90 \\
L foot width & ++ & 0.55 & + & 0.30 \\
R foot width & +- & 0.57 & + & 0.19 \\
KyL & +- & 0.35 & + & 0.47 \\
KyR & -+ & 0.22 & + & 0.19 \\
KyL & ++ & 0.92 & + & 0.67 \\
KyR & -+ & 0.33 & & 0.36 \\
\hline
\end{tabular}

As shown in Table 9, no statistically significant difference in the test parameters between the 7-year old girls and boys were observed. 
Table 10. Significance of the differences of the selected parameters between the groups of 8-year old girls and boys

\begin{tabular}{lcccc}
\hline \multicolumn{1}{r}{ Parameters } & $\begin{array}{c}\text { Samples } \\
(+;-)\end{array}$ & $\begin{array}{c}\text { Student's test } \\
(\mathrm{t})\end{array}$ & $\begin{array}{c}\text { Sample } \\
(+;-)\end{array}$ & \multicolumn{2}{c}{$\begin{array}{c}\text { Man-Whitney test } \\
(\mathrm{U})\end{array}$} \\
\hline Body weight & +- & 0.016 & + & $\mathbf{0 . 0 2 0 ^ { * }}$ \\
Body height & ++ & $0.004^{*}$ & + & 0.004 \\
L foot length & -- & 0.530 & + & $\mathbf{0 . 0 2 0 ^ { * }}$ \\
R foot length & -- & 0.510 & + & $0.040^{*}$ \\
L foot width & ++ & 0.580 & + & 0.230 \\
R foot width & -- & 0.280 & + & $0.046^{*}$ \\
KyL & +- & 0.340 & + & 0.380 \\
KyR & ++ & 0.460 & + & 0.460 \\
KyL & +- & 0.930 & + & 0.940 \\
KyR & -- & 0.560 & + & 0.170 \\
\hline
\end{tabular}

* Significant with $p<0.05$.

Statistically significant differences in body height, the length of the left and right foot and in the width of the right foot were observed between the groups 8-year old boys and girls (Table 10). The boys were taller and had longer feet, which points to their faster physical development in this age. No statistically significant differences were observed in the feet curvature.

The proportion of children with hollow foot arch was also determined for the tested groups. The largest percentage of such children, which amounted to $20 \%$, was noted in case of both boys and girls aged 8 (Tables 3 and 6). There were no differences between the right and left foot.

This may be attributable to many factors. It may be e.g. due to the fact that the tested children participated in recreational dance classes and karate classes at school. Increased physical activity, even recreational, fosters the development of the ligament-muscular system of the feet.

\section{Discussion}

A number of researchers explore the issue of the development of arch curvature in children at early school age. Studies show that from the time of birth, the foot grows at a regular pace, and the curvature of its arch becomes noticeable at about the age of 3 (Lizis, 2000). Gołąb, Lizis, and Ignasiak note that the age between 5-9 is the critical period of the most rapid development of the feet (Gołąb, 1980; Ignasiak, 1993; Lizis, 2000). Kurniewicz-Witczakowa points to the occurrence of dynamic changes in the feet curvature at the age between 3-7 (Kurniewicz-Witczakowa, 1996). As maintained by Lizis, the foot reaches maturity much earlier compared to other parameters of the body, such as the height, length, or width of the hand (Lizis, 1992). Considering the dynamic nature of the development of the foot in this period, particular attention should be paid to preventive care.

It is widely known that physical activity and normal body weight are the key factors that determine proper development of the feet (Lizis, 1992. Basing on an evaluation of the longitudinal foot arch curvature in preschool children, Mickle et al. maintain that the risk of flat feet increases together with body weight (Mickle, Steele, Munro 2006).

Te authors' own studies revealed that the parameters of the longitudinal arch curvature are appropriate. The obtained test results show that for both 7 and 8 year olds the curvature of the feet is normal for more than 
a half of the tested boys and girls. The percentage of boys with lowered longitudinal arch is greater (20 and $24 \%$ ) than girls (18 and $9 \%$ ) (Tables 3 and 6 ). These relationships are, however, statistically insignificant in terms of the sex (Table 9). No statistically significant differences in the curvature of the longitudinal arch were also observed between 7 and 8 year olds. In the tested group, the curvature of the longitudinal arch develops in the same manner for both boys and girls. Significant differences were observed, however, for 8 year old boys and girls between the length of the feet, and the weight and height of the body (Table 10). The boys grow faster and their feet are longer. This does not significantly affect the formation of the longitudinal arch of the foot.

Due to similar lifestyles and school duties of the 7 and 8 year olds, no statistically significant differences between the tested groups were found. The curvature of the longitudinal arch of the 7 year olds was similar to that of the 8 year olds. There were no obese children in the tested group. The participation in extracurricular activities (i.e. dance and karate lessons) and normal body weight positively affected the development of the feet structure of the tested children. This outcome is in line with the results quoted by Lizis and Mickle (Lizis, 1992; Mickle, 2006).

Dynamic growth of the feet and the applied loads affect the development of this part of the body. Feet develop as a succession of different stages (Rykała, Snela, Drzał-Grabiec, Podgórski, Nowicka, Kosiba, 2013). To enable appropriate correction it is essential to diagnose the early changes related to ligament-muscular insufficiency. The non-invasive nature of this method of evaluation of the longitudinal foot arch curvature enables regular monitoring of the development of the feet, to take preventive steps at appropriate stage.

\section{Conclusions}

1. The study has revealed statistically significant differences for 7 and 8 year old girls and boys between the weight and height of the body and the length of the feet.

2. No statistically significant relationships were found between in the curvature of the right and left foot between 7 and 8 year olds of either sex.

3. In the test groups of 7 year olds and 8 year olds, the vast majority of boys and girls had normal curvature of the longitudinal arch of the right and left foot.

4. Among 7 year olds, no statistically significant relationships were found for any parameter between girls and boys.

5. Among 8 year olds, there are statistically significant differences in the arithmetic average values between the girls' and boys' body height and weight, and the length and width of the right foot.

\section{References}

Demczuk-Włodarczyk, W. (2003). Budowa stopy w okresie rozwoju progresywnego człowieka. Studia i Monografie, 66. Wrocław: AWF.

Gołąb, S., Chrzanowska, M., Cadel, K., Sobiecki, J., Żarow, R., Lechowicz, W. (1980). Ontogenetyczna zmienność wymiarów stopy i podudzia oraz wady budowy stóp u młodzieży krakowskiej. Rocznik Naukowy, 17, 155-182. Kraków: AWF.

Ignasiak, Z., Jasiński, R., Zalewski, A. (1993). Dynamika wzrastania ręki i stopy u młodzieży wrocławskiej. Fizjoterapia, 1 (2), 40-44. Kasperczyk, T. (1994). Metody badania stóp. In: Wady postawy ciała (pp. 175-195). Kraków: Kasper.

Kurniewicz-Witczakowa, R. (1996). Kształtowanie się budowy stopy na tle analizy metod jej badania u dzieci i młodzieży warszawskiej. Prace i materiały naukowe IMD, 8, 10-11.

Lizis, P., Kasperczyk, T., Szmigiel, C., Red, J., Całka-Lizis, T., Emmerich, W., Ślężyński, J. (1992). Postawa ciała i jej związki z cechami morfologicznymi dzieci otyłych. In: Postawa ciała człowieka i metody jej oceny (pp. 99-107). Katowice: AWF. 
Lizis, P. (2000). Kształtowanie się wysklepienia łuku podłużnego stopy i problemy korekcji płaskostopia u dzieci i młodzieży w wieku rozwojowym. Podręczniki i Skrypty, 10. 10-17, 47-68. Krakow: AWF.

Mickle, K.J., Steele, J.R, Munro, B. (2006).The feet of overweight and obese young children: are they flat or fat? Obesity, 11 (14), 1949-1953.

Petrie, A., Sabin, C. (2006). Statystyka medyczna w zarysie. Warszawa: PZWL.

Rykała, J., Snela, S., Drzał-Grabiec, J., Podgórska, J., Nowicka, J., Kosiba, W. (2013). Ocena wysklepienia podłużnego i poprzecznego stóp w warunkach odciążenia i obciążenia masą własną u dzieci w wieku 7-10 lat. Przegląd Medyczny Uniwersytetu Rzeszowskiego i Narodowego Instytutu Leków w Warszawie, 2, 183-193.

Cite this article aS: Niewiadomska, M., Makris, M., Kotarska, K. (2018). Evaluation of the Curvature of the Longitudinal Foot Arch in Children aged 7 and 8 - A Pilot Study. Central European Journal of Sport Sciences and Medicine, 1 (21), 31-40. DOI: 10.18276/cej.2018.1-04. 